\title{
1 Genetic analysis of the STIM1 gene in chronic pancreatitis
}

2

3 Emmanuelle Masson, ${ }^{1,2, \dagger}$ Wen-Bin Zou, ${ }^{3,4, \dagger}$ Claudia Ruffert, ${ }^{5}$ Vanessa Holste, ${ }^{6}$ Patrick Michl, ${ }^{5}$

4 Joachim Mössner, ${ }^{7}$ Maren Ewers, ${ }^{6}$ Helmut Laumen, ${ }^{6} \mathrm{Hao}$ Wu, ${ }^{3,4}$ Dai-Zhan Zhou, ${ }^{8}$ Zhao-Shen Li, ${ }^{3,4}$

5 Dong Yu, ${ }^{9}$ Arnaud Boulling, ${ }^{1}$ Cédric Le Maréchal, ${ }^{1,2}$ David N. Cooper, ${ }^{10}$ Jian-Min Chen, ${ }^{1}$

6 Heiko Witt, ${ }^{6}$ Jonas Rosendahl, ${ }^{5}$ Zhuan Liao,,${ }^{3,4,}{ }^{*}$ Claude Férec ${ }^{1,3,{ }^{*}}$

7

$8 \quad{ }^{1}$ Univ Brest, Inserm, EFS, UMR 1078, GGB, F-29200 Brest, France

$9 \quad{ }^{2} \mathrm{CHU}$ Brest, Service de Génétique, Brest, France

$10{ }^{3}$ Department of Gastroenterology, Changhai Hospital, the Second Military Medical University,

11 Shanghai, China

12 4Shanghai Institute of Pancreatic Diseases, Shanghai, China

13 5Department of Internal Medicine I, Martin Luther University, Halle, Germany

$14{ }^{6}$ Paediatric Nutritional Medicine, Else Kröner-Fresenius Zentrum für Ernährungsmedizin (EKFZ),

15 Technische Universität München (TUM), Freising, Germany

$16{ }^{7}$ Department of Internal Medicine, Neurology and Dermatology, Division of Gastroenterology,

17 University of Leipzig, Leipzig, Germany

${ }^{8}$ Key Laboratory of Developmental Genetics and Neuropsychiatric Diseases (Ministry of Education),

Bio-X Institutes, Shanghai Jiao Tong University, Shanghai, China

${ }^{9}$ Center of Translational Medicine, the Second Military Medical University, Shanghai, China

${ }^{10}$ Institute of Medical Genetics, School of Medicine, Cardiff University, Cardiff, United Kingdom

†Emmanuelle Masson and Wen-Bin Zou share co-first authorship.

\section{*Correspondence to:}

Claude Férec, INSERM U1078 and UBO, 22 avenue Camille Desmoulins, 29200 Brest, France. email: claude.ferec@univ-brest.fr.

Zhuan Liao, Department of Gastroenterology, Changhai Hospital, The Second Military Medical University, 168 Changhai Road, Shanghai 200433, China. e-mail: liaozhuan@smmu.edu.cn. 


\section{ABSTRACT}

Chronic pancreatitis is a complex disease that involves many factors, both genetic and environmental. Over the past two decades, molecular genetic analysis of five genes that are highly expressed in human pancreatic acinar cells, namely PRSS1, PRSS2, SPINK1, CTRC and CTRB1/CTRB2, has established that a trypsin-dependent pathway plays a key role in the etiology of chronic pancreatitis. Since $\mathrm{Ca}^{2+}$ deregulation can lead to intracellular trypsin activation in experimental acute pancreatitis, we analyzed STIM1 (encoding stromal interaction molecule-1, the main regulator of $\mathrm{Ca}^{2+}$ homeostasis in pancreatic acinar cells) as a candidate modifier gene in French, German and Chinese patients with chronic pancreatitis. The French and German subjects were analyzed by Sanger sequencing whereas the Chinese subjects were analyzed by targeted next-generation sequencing confirmed by Sanger sequencing. A total of 37 rare coding variants (35 missense and 2 nonsense) were identified, which were enriched in patients as compared with controls $[2.28 \%(47 / 2,057)$ vs. $0.99 \%(33 / 3,322)$; odds ratio $=2.33, P=0.0001]$. This is the first large case-control study to demonstrate a putative association of rare STIM1 coding variants with chronic pancreatitis. Functional analysis will be required to clarify whether or not the rare STIM1 variants detected predispose to pancreatitis.

\section{INTRODUCTION}

Chronic pancreatitis is a complex disease that is defined as "a pathologic fibro-inflammatory syndrome of the pancreas in individuals with genetic, environmental and/or other risk factors who develop persistent pathologic responses to parenchymal injury or stress" (Whitcomb et al., 2016). Over the past two decades, molecular genetic analysis of five genes that are highly expressed in human pancreatic acinar cells, namely PRSS1 encoding cationic trypsinogen (Le Maréchal et al., 2006; Whitcomb et al., 1996), PRSS2 encoding anionic trypsinogen (Witt et al., 2006), SPINK1 encoding pancreatic secretory trypsin inhibitor (Witt et al., 2000), CTRC encoding chymotrypsin C (Masson et al., 2008; Rosendahl et al., 2008) and CTRB1-CTRB2 encoding chymotrypsin B1 and B2 (Rosendahl et al., 2018), has established a trypsin-dependent pathway in the etiology of chronic pancreatitis (Hegyi and Sahin-Toth, 2017).

The majority of patients with chronic pancreatitis had prior clinically recognized acute pancreatitis (LaRusch et al., 2015), an acute inflammatory disease of the pancreas postulated to be an autodigestive disease triggered by prematurely activated trypsin within the pancreas (Chiari, 1896). The association of gain-of-function PRSS1 variants with both recurrent acute pancreatitis and chronic pancreatitis (Gorry et al., 1997; Whitcomb et al., 1996) not only provided support for

63 Chiari's original hypothesis (Chiari, 1896) but has also contributed to the Sentinel Acute

64 Pancreatitis Event model for the development of chronic pancreatitis (Whitcomb, 1999). 
Importantly, successive developments of spontaneous acute pancreatitis and chronic pancreatitis have recently been observed in genetically modified mice that carried a heterozygous p.Asp23Ala mutation within the activation peptide of the mouse cationic trypsinogen (Prss1) T7 isoform (the p.Asp23Ala mutant autoactivates to trypsin 50-fold faster than wild-type) (Geisz and Sahin-Tóth, 2018).

The above notwithstanding, our understanding of the early events leading to pancreatitis is still rather limited. In this regard, prolonged and global $\mathrm{Ca}^{2+}$ elevation (elicited by bile, alcohol metabolites and other causes) has been described to result in trypsin activation, vacuolization and necrosis of the pancreatic acinar cells in experimental acute pancreatitis (review in (Li et al., 2014)); and stromal interaction molecule-1 (STIM1) is a key regulator for $\mathrm{Ca}^{2+}$ homeostasis in both nonexcitable and excitable cells (Yuan et al., 2009). These findings suggest that variants in the STIM1 gene may contribute to the early steps of pancreatitis by disturbing $\mathrm{Ca}^{2+}$ homeostasis within the pancreatic tissue.

Variants in the STIM1 gene have been previously associated a number of diseases such as immunodeficiency and autoimmunity (Picard et al., 2009; Shaw et al., 2013), a novel syndrome of amelogenesis imperfecta and hypohidrosis (Parry et al., 2016), tubular-aggregate myopathy (Bohm et al., 2013; Nesin et al., 2014; Noury et al., 2017), or Stormorken syndrome (Misceo et al., 2014; Morin et al., 2014). Also, tubular aggregate myopathy and Stormorken syndrome patients carrying STIM1 variants additionally manifested psychiatric disorders (Harris et al., 2017). Moreover, Sofia and colleagues have recently analyzed the STIM1 gene (included within a panel of 70 genes related to six different pancreatic pathways) in 80 patients with idiopathic chronic pancreatitis (ICP) and found three missense mutations [i.e., c.1310G>A (p.Cys437Tyr), c.1589G>A (p.Arg530His), and c.2246G>A (p.Arg749His)] in different patients (Sofia et al., 2016). In addition to the relatively small number of patients analyzed, this study was limited by the lack of data from a corresponding control population. Herein, we report our findings from a comprehensive variant analysis of the STIM1 gene in three ICP cohorts.

\section{PATIENTS AND METHODS}

\section{Patients}

This study included 436 French, 517 German and 1,104 Chinese patients with ICP (i.e., absence of both a positive family history and any of the following external precipitating factors, namely alcohol abuse, post-traumatic, hypercalcemic, hyperlipidemic and autoimmune) and corresponding healthy controls. The diagnosis of chronic pancreatitis was made as previously described (Witt et al., 2013; Zou et al., 2016). Informed consent was obtained from each patient and the study was approved by the respective ethics committees. 


\section{Variant screening}

The French and German subjects were analyzed by Sanger sequencing; three multiplex PCRs were designed to amplify the entire coding sequence and flanking intronic sequences of the STIM1 gene (see additional file, Figures. S1 and S2). The Chinese subjects were analyzed by targeted next-generation sequencing followed by Sanger sequencing confirmation, essentially as previously described (Wu et al., 2017; Zou et al., 2018), the primer sequences are provided in Additional file, Figure S3.

\section{Variant nomenclature and reference sequences}

Variant nomenclature followed Human Genome Variation Society recommendations

110 (http://www.hgvs.org/mutnomen/recs.html) (den Dunnen et al., 2016). GenBank accession number NM_003156.3 was used as the STIM1 mRNA reference sequence. STIM1 genomic sequence was obtained from human GRCh38/hg38 (https://genome.ucsc.edu/).

\section{Pathogenicity prediction}

115 This was performed using the Combined Annotation-Dependent Depletion (CADD) method (Kircher et al., 2014) available at https://cadd.gs.washington.edu/.

\section{Statistical analyses}

119 The assessment of statistical significance of the differences between the carrier frequencies of the 120 STIM1 variants in patients and controls was performed by the $2 \times 2$ contingency table available at 121 http://vassarstats.net/odds2x2.html. The difference was considered as being statistically significant when the $P$ value was $\leq 0.05$.

\section{RESULTS AND DISCUSSION}

125 Given the importance of $\mathrm{Ca}^{2+}$ signaling for the regulation of pancreatic zymogen activation and the key role of STIM1 in $\mathrm{Ca}^{2+}$ homeostasis, we analyzed the STIM1 gene as a candidate modifier gene for chronic pancreatitis. Employing Sanger sequencing, we first analyzed the entire coding sequence (2,058 bp; NM_003156.3) and exon/intron boundaries of the 12-exon STIM1 gene in 436 French ICP patients and 1,005 controls, and then repeated this analysis with 517 German ICP patients and 1,121 controls. Our subsequent analysis was limited to coding sequence variants that resulted in amino acid changes and intronic variants that affected canonical donor/acceptor splice

132 sites. Eight such variants were identified in the French cohort and ten in the German cohort; all 133 these variants were single nucleotide substitutions and all were predicted to result in missense 134 substitutions (Additional file, Tables S1 and S2). Since all detected variants were rare variants 
135

(defined as having a minor allele frequency of $<0.5 \%$ in the control population as previously described (Manolio et al., 2009; Tennessen et al., 2012), we first performed aggregate association analysis in the context of each cohort. A significant enrichment of rare variants in patients as compared to controls was noted in the French cohort (odds ratio $(\mathrm{OR})=4.04, P=0.002$ ) but not in the German cohort $(\mathrm{OR}=1.64, P=0.26)$ (Table 1$)$.

We also analyzed the STIM1 gene in 1,104 Chinese ICP patients and 1,196 controls by means of targeted sequencing followed by Sanger sequencing validation. A total of 24 rare variants were identified (Additional file, Table S3), which when taken together were significantly overrepresented in patients as compared to controls $(\mathrm{OR}=2.03, P=0.03$; Table 1$)$. A Breslow-Day test for homogeneity of the ORs (https://www.prostatservices.com/) between the French, German and Chinese cohorts showed no significant difference $(P=0.14)$. We therefore combined data from these three cohorts (Table 2), the carrier frequency of the aggregated rare variants being significantly higher in patients than in controls (OR $=2.33, P=0.0001$; Table 1$)$.

Our comprehensive analysis of the STIM1 gene in three ICP cohorts identified a significant enrichment of rare coding STIM1 variants in patients as compared to controls by means of aggregate association analysis (Table 1). Notably, none of the identified 37 rare STIM1 variants correspond to those previously reported to cause or predispose to other diseases (Lacruz and Feske, 2015), potentially strengthening the notion of the tissue-specific effects of different STIM1 variants. However, pathogenicity prediction by means of the CADD method yielded similar findings among the three groups of variants namely, (i) variants found in only patients, (ii) variants found in both patients and controls and (iii) variants found in only controls (Table 2).

In summary, this is the first large case-control study to demonstrate a putative association of rare STIM1 coding variants with chronic pancreatitis. Functional analysis will be required to clarify whether or not rare coding STIM1 variants predispose to pancreatitis.

\section{Disclosure statement}

The authors declare no conflict of interest.

\section{Funding information}

Support for this study came from the National Natural Science Foundation of China (Grant Nos.81422010 and 81470884; to ZL), the Shuguang Program of Shanghai (Grant No. 15SG33; to ZL), the Chang Jiang Scholars Program of Ministry of Education, China (Grant No. Q2015190; to ZL), the Precision Medicine Program of the Second Military Medical University (Grant No.2017JZ02; to ZSL), the Scientific Innovation Program of Shanghai Municipal Education Committee (to ZL); the Else Kröner-Fresenius-Stiftung (EKFS) (to H.W.); the Deutsche 
Forschungsgemeinschaft (DFG) grants RO 3929/1-1, RO 3929/2-1 \& RO3929/5-1 (to J.R.) and by a grant of the Colora Stiftung $\mathrm{GmbH}$ (to J.R.); the Association des Pancréatites Chroniques Héréditaires and the Institut National de la Santé et de la Recherche Médicale (INSERM), France.

\section{REFERENCES}

Bohm J, Chevessier F, Maues De Paula A, Koch C, Attarian S, Feger C, Hantai D, Laforet P, Ghorab K, Vallat $J M$, Fardeau M, Figarella-Branger D, Pouget J, Romero NB, Koch M, Ebel C, Levy N, Krahn M, Eymard $B$, Bartoli M, Laporte J. Constitutive activation of the calcium sensor STIM1 causes tubular-aggregate myopathy. Am J Hum Genet 2013; 92: 271-278.

Chiari H. Über Selbstverdauung des menschlichen Pankreas. Z. Heilkunde 1896; 17: 69-96.

den Dunnen JT, Dalgleish R, Maglott DR, Hart RK, Greenblatt MS, McGowan-Jordan J, Roux AF, Smith T, Antonarakis SE, Taschner PE. HGVS recommendations for the description of sequence variants: 2016 update. Hum Mutat 2016; 37: 564-569.

Geisz A, Sahin-Tóth M. A preclinical model of chronic pancreatitis driven by trypsinogen autoactivation. Nat Commun 2018; 9: 5033.

Gorry MC, Gabbaizedeh D, Furey W, Gates LK, Jr., Preston RA, Aston CE, Zhang Y, Ulrich C, Ehrlich GD, Whitcomb DC. Mutations in the cationic trypsinogen gene are associated with recurrent acute and chronic pancreatitis. Gastroenterology 1997; 113: 1063-1068.

Harris E, Burki U, Marini-Bettolo C, Neri M, Scotton C, Hudson J, Bertoli M, Evangelista T, Vroling B, Polvikoski T, Roberts M, Topf A, Bushby K, McArthur D, Lochmuller H, Ferlini A, Straub V, Barresi R. Complex phenotypes associated with STIM1 mutations in both coiled coil and EF-hand domains. Neuromuscul Disord 2017; 27: 861-872.

Hegyi E, Sahin-Toth M. Genetic risk in chronic pancreatitis: the trypsin-dependent pathway. Dig Dis Sci 2017; 62: 1692-1701.

Kircher M, Witten DM, Jain P, O'Roak BJ, Cooper GM, Shendure J. A general framework for estimating the relative pathogenicity of human genetic variants. Nat Genet 2014; 46: 310-315.

Lacruz RS, Feske S. Diseases caused by mutations in ORAI1 and STIM1. Ann N Y Acad Sci 2015; 1356: 45-79.

LaRusch J, Lozano-Leon A, Stello K, Moore A, Muddana V, O'Connell M, Diergaarde B, Yadav D, Whitcomb DC. The common chymotrypsinogen C (CTRC) variant G60G (C.180T) increases risk of chronic pancreatitis but not recurrent acute pancreatitis in a north American population. Clin Transl Gastroenterol 2015; 6: e68.

Le Maréchal C, Masson E, Chen JM, Morel F, Ruszniewski P, Levy P, Férec C. Hereditary pancreatitis caused by triplication of the trypsinogen locus. Nat Genet 2006; 38: 1372-1374.

Li J, Zhou R, Zhang J, Li ZF. Calcium signaling of pancreatic acinar cells in the pathogenesis of pancreatitis. World J Gastroenterol 2014; 20: 16146-16152.

Manolio TA, Collins FS, Cox NJ, Goldstein DB, Hindorff LA, Hunter DJ, McCarthy MI, Ramos EM, Cardon LR, Chakravarti A, Cho JH, Guttmacher AE, Kong A, Kruglyak L, Mardis E, Rotimi CN, Slatkin M, Valle D, Whittemore AS, Boehnke M, Clark AG, Eichler EE, Gibson G, Haines JL, Mackay TF, McCarroll SA, Visscher PM. Finding the missing heritability of complex diseases. Nature 2009; 461: 747-753.

Masson E, Chen JM, Scotet V, Le Maréchal C, Férec C. Association of rare chymotrypsinogen C (CTRC) gene variations in patients with idiopathic chronic pancreatitis. Hum Genet 2008; 123: 83-91.

Misceo D, Holmgren A, Louch WE, Holme PA, Mizobuchi M, Morales RJ, De Paula AM, Stray-Pedersen A, Lyle R, Dalhus B, Christensen G, Stormorken H, Tjonnfjord GE, Frengen E. A dominant STIM1 mutation causes Stormorken syndrome. Hum Mutat 2014; 35: 556-564.

Morin G, Bruechle NO, Singh AR, Knopp C, Jedraszak G, Elbracht M, Bremond-Gignac D, Hartmann K, Sevestre H, Deutz P, Herent D, Nurnberg P, Romeo B, Konrad K, Mathieu-Dramard M, Oldenburg J, 
Bourges-Petit E, Shen Y, Zerres K, Ouadid-Ahidouch H, Rochette J. Gain-of-Function Mutation in STIM1 (P.R304W) Is Associated with Stormorken Syndrome. Hum Mutat 2014; 35: 1221-1232. Nesin V, Wiley G, Kousi M, Ong EC, Lehmann T, Nicholl DJ, Suri M, Shahrizaila N, Katsanis N, Gaffney PM, Wierenga KJ, Tsiokas L. Activating mutations in STIM1 and ORAI1 cause overlapping syndromes of tubular myopathy and congenital miosis. Proc Natl Acad Sci U S A 2014; 111: 4197-4202.

Noury JB, Bohm J, Peche GA, Guyant-Marechal L, Bedat-Millet AL, Chiche L, Carlier RY, Malfatti E, Romero NB, Stojkovic T. Tubular aggregate myopathy with features of Stormorken disease due to a new STIM1 mutation. Neuromuscul Disord 2017; 27: 78-82.

Parry DA, Holmes TD, Gamper N, El-Sayed W, Hettiarachchi NT, Ahmed M, Cook GP, Logan CV, Johnson CA, Joss S, Peers C, Prescott K, Savic S, Inglehearn CF, Mighell AJ. A homozygous STIM1 mutation impairs store-operated calcium entry and natural killer cell effector function without clinical immunodeficiency. J Allergy Clin Immunol 2016; 137: 955-957 e958.

Picard C, McCarl CA, Papolos A, Khalil S, Luthy K, Hivroz C, LeDeist F, Rieux-Laucat F, Rechavi G, Rao A, Fischer A, Feske S. STIM1 mutation associated with a syndrome of immunodeficiency and autoimmunity. N Engl J Med 2009; 360: 1971-1980.

Rosendahl J, Kirsten H, Hegyi E, Kovacs P, Weiss FU, Laumen H, Lichtner P, Ruffert C, Chen JM, Masson E, Beer S, Zimmer C, Seltsam K, Algul H, Buhler F, Bruno MJ, Bugert P, Burkhardt R, Cavestro GM, Cichoz-Lach H, Farre A, Frank J, Gambaro G, Gimpfl S, Grallert H, Griesmann H, Grutzmann R, Hellerbrand C, Hegyi P, Hollenbach M, lordache S, Jurkowska G, Keim V, Kiefer F, Krug S, Landt O, Leo MD, Lerch MM, Levy P, Loffler M, Lohr M, Ludwig M, Macek M, Malats N, Malecka-Panas E, Malerba G, Mann K, Mayerle J, Mohr S, Te Morsche RHM, Motyka M, Mueller S, Muller T, Nothen MM, Pedrazzoli S, Pereira SP, Peters A, Pfutzer R, Real FX, Rebours V, Ridinger M, Rietschel M, Rosmann E, Saftoiu A, Schneider A, Schulz HU, Soranzo N, Soyka M, Simon P, Skipworth J, Stickel F, Strauch K, Stumvoll M, Testoni PA, Tonjes A, Werner L, Werner J, Wodarz N, Ziegler M, Masamune A, Mossner J, Ferec C, Michl P, J PHD, Witt H, Scholz M, Sahin-Toth M, all members of the PanEuropean Working group on ACP. Genome-wide association study identifies inversion in the CTRB1-CTRB2 locus to modify risk for alcoholic and non-alcoholic chronic pancreatitis. Gut 2018; 67: 1855-1863.

Rosendahl J, Witt H, Szmola R, Bhatia E, Ozsvari B, Landt O, Schulz HU, Gress TM, Pfutzer R, Lohr M, Kovacs $P$, Bluher $M$, Stumvoll M, Choudhuri G, Hegyi $P$, te Morsche RH, Drenth JP, Truninger K, Macek $M$, Jr., Puhl G, Witt U, Schmidt H, Buning C, Ockenga J, Kage A, Groneberg DA, Nickel R, Berg T, Wiedenmann B, Bodeker H, Keim V, Mossner J, Teich N, Sahin-Toth M. Chymotrypsin C (CTRC) variants that diminish activity or secretion are associated with chronic pancreatitis. Nat Genet 2008; 40: 78-82.

Shaw PJ, Qu B, Hoth M, Feske S. Molecular regulation of CRAC channels and their role in lymphocyte function. Cell Mol Life Sci 2013; 70: 2637-2656.

Sofia VM, Da Sacco L, Surace C, Tomaiuolo AC, Genovese S, Grotta S, Gnazzo M, Petrocchi S, Ciocca L, Alghisi F, Montemitro E, Martemucci L, Elce A, Lucidi V, Castaldo G, Angioni A. Extensive molecular analysis suggested the strong genetic heterogeneity of idiopathic chronic pancreatitis. Mol Med 2016; 22: 300-309.

Tennessen JA, Bigham AW, O'Connor TD, Fu W, Kenny EE, Gravel S, McGee S, Do R, Liu X, Jun G, Kang HM, Jordan D, Leal SM, Gabriel S, Rieder MJ, Abecasis G, Altshuler D, Nickerson DA, Boerwinkle E, Sunyaev S, Bustamante CD, Bamshad MJ, Akey JM, Broad GO, Seattle GO, Project NES. Evolution and functional impact of rare coding variation from deep sequencing of human exomes. Science 2012; 337: 64-69.

Whitcomb DC. Hereditary pancreatitis: new insights into acute and chronic pancreatitis. Gut 1999; 45: 317322. 
Whitcomb DC, Frulloni L, Garg P, Greer JB, Schneider A, Yadav D, Shimosegawa T. Chronic pancreatitis: An international draft consensus proposal for a new mechanistic definition. Pancreatology 2016; 16: 218-224.

Whitcomb DC, Gorry MC, Preston RA, Furey W, Sossenheimer MJ, Ulrich CD, Martin SP, Gates LK, Jr., Amann ST, Toskes PP, Liddle R, McGrath K, Uomo G, Post JC, Ehrlich GD. Hereditary pancreatitis is caused by a mutation in the cationic trypsinogen gene. Nat Genet 1996; 14: 141-145.

Witt H, Beer S, Rosendahl J, Chen JM, Chandak GR, Masamune A, Bence M, Szmola R, Oracz G, Macek M, Jr., Bhatia E, Steigenberger S, Lasher D, Buhler F, Delaporte C, Tebbing J, Ludwig M, Pilsak C, Saum K, Bugert P, Masson E, Paliwal S, Bhaskar S, Sobczynska-Tomaszewska A, Bak D, Balascak I, Choudhuri G, Nageshwar Reddy D, Rao GV, Thomas V, Kume K, Nakano E, Kakuta Y, Shimosegawa T, Durko L, Szabo A, Schnur A, Hegyi P, Rakonczay Z, Jr., Pfutzer R, Schneider A, Groneberg DA, Braun M, Schmidt $H$, Witt $U$, Friess $H$, Algul $H$, Landt $O$, Schuelke $M$, Kruger $R$, Wiedenmann B, Schmidt $F$, Zimmer KP, Kovacs P, Stumvoll M, Bluher M, Muller T, Janecke A, Teich N, Grutzmann R, Schulz HU, Mossner J, Keim V, Lohr M, Ferec C, Sahin-Toth M. Variants in CPA1 are strongly associated with early onset chronic pancreatitis. Nat Genet 2013; 45: 1216-1220.

Witt H, Luck W, Hennies HC, Classen M, Kage A, Lass U, Landt O, Becker M. Mutations in the gene encoding the serine protease inhibitor, Kazal type 1 are associated with chronic pancreatitis. Nat Genet 2000; 25: 213-216.

Witt H, Sahin-Tóth M, Landt O, Chen JM, Kahne T, Drenth JP, Kukor Z, Szepessy E, Halangk W, Dahm S, Rohde K, Schulz HU, Le Marechal C, Akar N, Ammann RW, Truninger K, Bargetzi M, Bhatia E, Castellani C, Cavestro GM, Cerny M, Destro-Bisol G, Spedini G, Eiberg H, Jansen JB, Koudova M, Rausova E, Macek M, Jr., Malats N, Real FX, Menzel HJ, Moral P, Galavotti R, Pignatti PF, Rickards O, Spicak J, Zarnescu NO, Bock W, Gress TM, Friess H, Ockenga J, Schmidt H, Pfutzer R, Lohr M, Simon P, Weiss FU, Lerch MM, Teich N, Keim V, Berg T, Wiedenmann B, Luck W, Groneberg DA, Becker M, Keil T, Kage A, Bernardova J, Braun M, Guldner C, Halangk J, Rosendahl J, Witt U, Treiber M, Nickel $\mathrm{R}$, Ferec $\mathrm{C}$. A degradation-sensitive anionic trypsinogen (PRSS2) variant protects against chronic pancreatitis. Nat Genet 2006; 38: 668-673.

Wu H, Zhou DZ, Berki D, Geisz A, Zou WB, Sun XT, Hu LH, Zhao ZH, Zhao AJ, He L, Cooper DN, Férec C, Chen $J M$, Li ZS, Sahin-Tóth M, Liao Z. No significant enrichment of rare functionally defective CPA1 variants in a large Chinese idiopathic chronic pancreatitis cohort. Hum Mutat 2017; 38: 959-963.

Yuan JP, Kim MS, Zeng W, Shin DM, Huang G, Worley PF, Muallem S. TRPC channels as STIM1-regulated SOCs. Channels (Austin) 2009; 3: 221-225.

Zou WB, Boulling A, Masamune A, Issarapu P, Masson E, Wu H, Sun XT, Hu LH, Zhou DZ, He L, Fichou Y, Nakano E, Hamada S, Kakuta Y, Kume K, Isayama H, Paliwal S, Mani KR, Bhaskar S, Cooper DN, Férec C, Shimosegawa T, Chandak GR, Chen JM, Li ZS, Liao Z. No association between CEL-HYB hybrid allele and chronic pancreatitis in Asian populations. Gastroenterology 2016; 150: 1558-1560.e5.

Zou WB, Tang XY, Zhou DZ, Qian YY, Hu LH, Yu FF, Yu D, Wu H, Deng SJ, Lin JH, Zhao AJ, Zhao ZH, Wu HY, Zhu JH, Qian W, Wang L, Xin L, Wang MJ, Wang LJ, Fang X, He L, Masson E, Cooper DN, Férec C, Li ZS, Chen JM, Liao Z. SPINK1, PRSS1, CTRC, and CFTR genotypes influence disease onset and clinical outcomes in chronic pancreatitis. Clin Trans/ Gastroenterol 2018; 9: 204. 
303 Table 1. Prevalence of STIM1 variants in ICP patients versus controls in the French, German and 304 Chinese Populations

\begin{tabular}{|l|l|l|l|l|l|}
\hline Population & Cases & Controls & Odds & $\begin{array}{l}\text { 95\% } \\
\text { ratio } \\
\text { confidence } \\
\text { interval }\end{array}$ & $\boldsymbol{P}$ value \\
\cline { 2 - 6 } & $+/ \mathrm{n}(\%)$ & $+/ \mathrm{n}(\%)$ & & $1.58-10.32$ & 0.002 \\
\hline French & $12 / 436(2.75)$ & $7 / 1,005(0.70)$ & 4.04 & $0.69-3.91$ & 0.26 \\
\hline German & $9 / 517(1.74)$ & $12 / 1,121(1.07)$ & 1.64 & 0.03 \\
\hline Chinese & $26 / 1,104(2.36)$ & $14 / 1,196(1.17)$ & 2.03 & $1.06-3.92$ & 0.03 \\
\hline $\begin{array}{l}\text { All three } \\
\text { combined }\end{array}$ & $47 / 2,057(2.28)$ & $33 / 3,322(0.99)$ & 2.33 & $1.49-3.65$ & 0.0001 \\
\hline
\end{tabular}


Table 2. STIM1 variants in the combined French, German and Chinese cohorts

\begin{tabular}{|c|c|c|c|c|c|c|c|c|c|}
\hline \multirow[t]{2}{*}{ Exon } & \multirow[t]{2}{*}{$\begin{array}{l}\text { Nucleotide } \\
\text { change }\end{array}$} & \multirow[t]{2}{*}{$\begin{array}{l}\text { Amino acid } \\
\text { change }\end{array}$} & \multicolumn{2}{|c|}{$\begin{array}{l}\text { Patients } \\
(n=2,057)\end{array}$} & \multicolumn{2}{|c|}{$\begin{array}{l}\text { Controls } \\
(n=3,322)\end{array}$} & \multirow[t]{2}{*}{ rs number } & \multirow{2}{*}{$\begin{array}{l}\text { Allele } \\
\text { frequency in } \\
\text { gnomAD }\end{array}$} & \multirow[t]{2}{*}{$\begin{array}{l}\text { CADD } \\
\text { score }\end{array}$} \\
\hline & & & $+(\%)$ & Population(s) & $+(\%)$ & Population(s) & & & \\
\hline \multicolumn{10}{|c|}{ Variants detected in patients only } \\
\hline 1 & c. $91 \mathrm{G}>\mathrm{C}$ & p.Ala31Pro & $1(0.05)$ & $\mathrm{F}$ & $0(0)$ & & rs368091975 & $1.19 \mathrm{e}-5$ & 16.10 \\
\hline 1 & c. $107 \mathrm{C}>\mathrm{T}$ & p.Ser36Leu & $1(0.05)$ & $\mathrm{G}$ & $0(0)$ & & rs200907515 & $3.18 e-5$ & 13.72 \\
\hline 1 & c. $112 \mathrm{G}>\mathrm{C}$ & p.Ala38Pro & $1(0.05)$ & $\mathrm{F}$ & $0(0)$ & & rs774499633 & No & 14.95 \\
\hline 1 & c. $113 \mathrm{C}>\mathrm{T}$ & p.Ala38Val & $1(0.05)$ & C & $0(0)$ & & No & No & 13.93 \\
\hline 4 & c. $454 \mathrm{G}>\mathrm{A}$ & p.Glu152Lys ${ }^{a}$ & $3(0.15)$ & $\mathrm{C}(1), \mathrm{F}(2)$ & $0(0)$ & & rs143916878 & $1.16 \mathrm{e}-4$ & 23.2 \\
\hline 6 & c. $747 G>C$ & p.Glu249Asp & $1(0.05)$ & $\mathrm{C}$ & $0(0)$ & & No & No & 18.57 \\
\hline 9 & c. $1231 A>G$ & p.Thr411Ala & $1(0.09)$ & C & $0(0)$ & & No & No & 18.54 \\
\hline 11 & c. $1498 \mathrm{C}>\mathrm{T}$ & p.Arg500Trp & $1(0.05)$ & C & $0(0)$ & & rs772902514 & $1.59 e-5$ & 33 \\
\hline 12 & c. $1562 \mathrm{C}>\mathrm{T}$ & p.Ser521Leu & $2(0.10)$ & $\mathrm{C}(1), \mathrm{G}(1)$ & $0(0)$ & & rs745539009 & $1.59 e-5$ & 24.5 \\
\hline 12 & c. $1595 \mathrm{G}>\mathrm{A}$ & p.Arg532His & $1(0.05)$ & C & $0(0)$ & & rs771442242 & $7.96 \mathrm{e}-6$ & 26.5 \\
\hline 12 & c. $1615 \mathrm{C}>\mathrm{T}$ & p.GIn539Ter & $1(0.05)$ & C & $0(0)$ & & No & No & 41 \\
\hline 12 & c. $1668 C>G$ & p.Ser556Arg & $5(0.24)$ & $\mathrm{C}$ & $0(0)$ & & rs201543900 & $4.24 \mathrm{e}-5$ & 22.6 \\
\hline 12 & c. $1801 \mathrm{C}>\mathrm{T}$ & p.Pro601Ser & $1(0.05)$ & $\mathrm{G}$ & $0(0)$ & & rs200960094 & $3.98 e-5$ & 16.68 \\
\hline 12 & c. $1808 \mathrm{C}>\mathrm{T}$ & p.Ala603Val & $1(0.05)$ & C & $0(0)$ & & rs749622475 & $1.19 e-5$ & 19.32 \\
\hline 12 & c. $1843 \mathrm{C}>\mathrm{T}$ & p.Arg615Cys & $3(0.15)$ & $\mathrm{C}$ & $0(0)$ & & rs560566339 & $1.19 e-5$ & 28.5 \\
\hline 12 & c. $2012 \mathrm{G}>\mathrm{A}$ & p.Arg671Gln & $1(0.05)$ & C & $0(0)$ & & rs779204802 & $8.04 \mathrm{e}-6$ & 24.3 \\
\hline \multicolumn{10}{|c|}{ Variants detected in patients and controls } \\
\hline 4 & c. $458 \mathrm{C}>\mathrm{T}$ & p.Thr153lle & $3(0.15)$ & $F(1), G(2)$ & $1(0.03)$ & $\mathrm{F}$ & rs144602692 & $1.94 \mathrm{e}-4$ & 23.8 \\
\hline
\end{tabular}




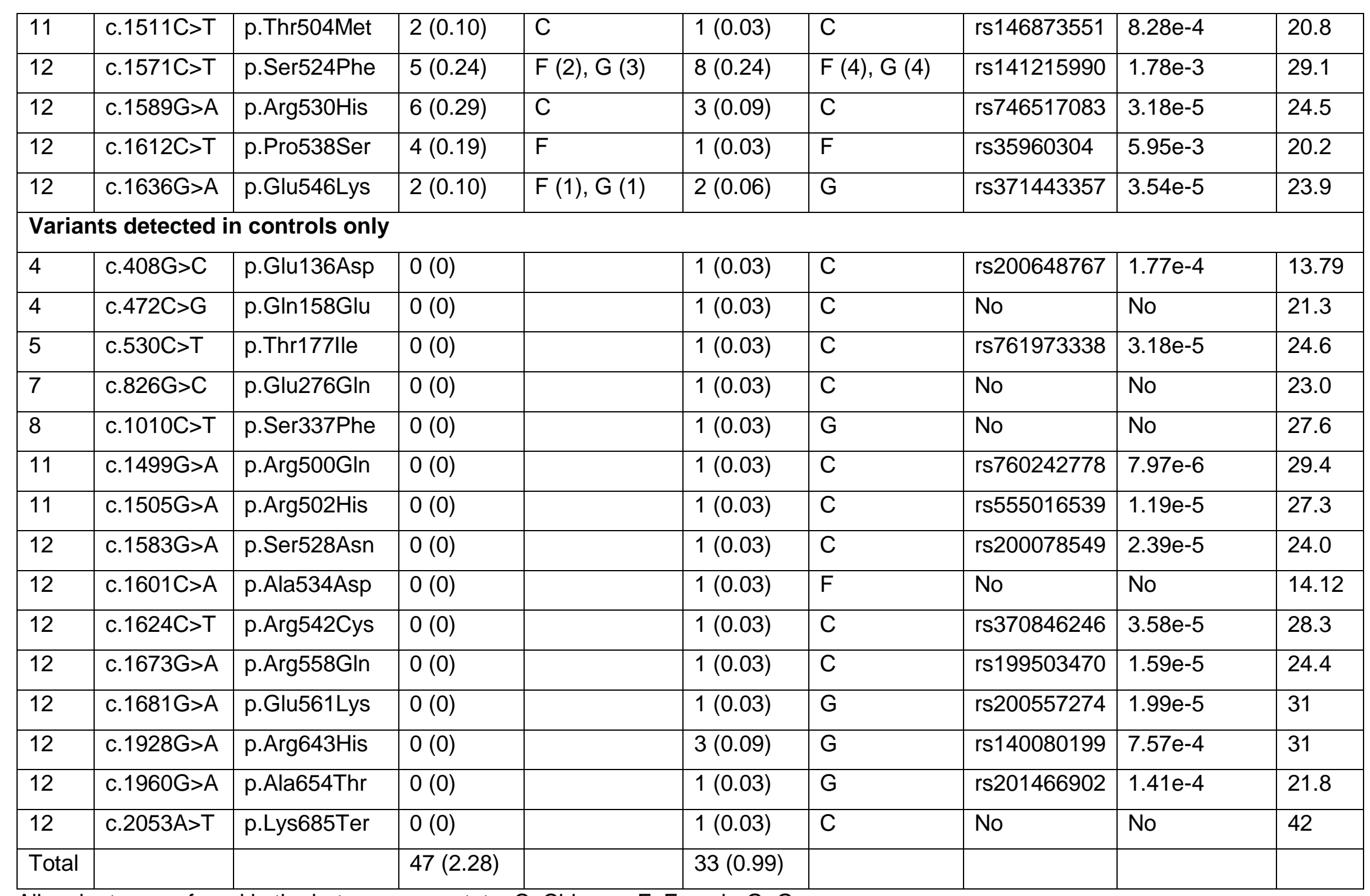

All variants were found in the heterozygous state. C, Chinese. F, French. G, Germany. 